University of Wollongong

Research Online

Faculty of Engineering and Information

Faculty of Engineering and Information

Sciences - Papers: Part A

Sciences

$1-1-2015$

Understanding risk communication gaps through e-government website and Twitter hashtag content analyses: the case of Indonesia's Mt. Sinabung eruption

Akemi Takeoka Chatfield

University of Wollongong, akemi@uow.edu.au

Christopher G. Reddick

University of Texas at San Antonio

Follow this and additional works at: https://ro.uow.edu.au/eispapers

Part of the Engineering Commons, and the Science and Technology Studies Commons

Research Online is the open access institutional repository for the University of Wollongong. For further information contact the UOW Library: research-pubs@uow.edu.au 


\title{
Understanding risk communication gaps through e-government website and Twitter hashtag content analyses: the case of Indonesia's Mt. Sinabung eruption
}

\author{
Abstract \\ Despite operational volcano surveillance using meteorological satellite, thermal remote sensing and \\ infrared camera technologies, predicting a volcano's hazardous activity and explosive eruption, with any \\ accuracy, remains nearly impossible. Volcanic hazards and risk literature identifies risk communication as \\ critical but insufficiently understood. This paper, therefore, investigates disaster risk communications \\ during Indonesia's Mt. Sinabung eruptions in February 2014, causing 16 deaths and continuous \\ evacuations of 30,000 residents. We critically examined one-way government-to-citizens communications \\ via e-government websites and Twitter and citizens' multi-directional communications via \#sinabung \\ hashtag for sharing volcano risk perceptions about affected villagers. Our Twitter analysis of \#sinabung \\ found evidence for the absence of government engagement in risk perception communications and \\ leadership in responding to the Indonesian public's expressed concerns for the Mt. Sinabung disaster. For \\ governments that would implement citizen-centric e-governance, Twitter can be used effectively as a \\ multi-directional risk communication tool to quickly and effectively share risk perceptions and disaster \\ information with the public.

\section{Disciplines} \\ Engineering | Science and Technology Studies

\section{Publication Details} \\ Chatfield, A. Takeoka. \& Reddick, C. G. (2015). Understanding risk communication gaps through e- \\ government website and Twitter hashtag content analyses: the case of Indonesia's Mt. Sinabung \\ eruption. Journal of Homeland Security and Emergency Management, 12 (2), 351-385.
}




\title{
Akemi Takeoka Chatfield and Christopher G. Reddick* Understanding Risk Communication Gaps through E-Government Website and Twitter Hashtag Content Analyses: The Case of Indonesia's Mt. Sinabung Eruption
}

\begin{abstract}
Despite operational volcano surveillance using meteorological satellite, thermal remote sensing and infrared camera technologies, predicting a volcano's hazardous activity and explosive eruption, with any accuracy, remains nearly impossible. Volcanic hazards and risk literature identifies risk communication as critical but insufficiently understood. This paper, therefore, investigates disaster risk communications during Indonesia's Mt. Sinabung eruptions in February 2014, causing 16 deaths and continuous evacuations of 30,000 residents. We critically examined one-way government-to-citizens communications via e-government websites and Twitter and citizens' multi-directional communications via \#sinabung hashtag for sharing volcano risk perceptions about affected villagers. Our Twitter analysis of \#sinabung found evidence for the absence of government engagement in risk perception communications and leadership in responding to the Indonesian public's expressed concerns for the Mt. Sinabung disaster. For governments that would implement citizen-centric e-governance, Twitter can be used effectively as a multi-directional risk communication tool to quickly and effectively share risk perceptions and disaster information with the public.
\end{abstract}

Keywords: citizen-centric e-governance; Indonesia; Mt. Sinabung eruption; political efficacy; risk perception communication; social media; Twitter hashtag; volcanic hazards and risk.

DOI 10.1515/jhsem-2014-0086

\footnotetext{
*Corresponding author: Christopher G. Reddick, Professor and Department Chair, Department of Public Administration, College of Public Policy, The University of Texas at San Antonio, 501 W. César E. Chávez Boulevard, San Antonio, Texas 78207-4415, USA, e-mail: chris.reddick@utsa.edu
}

Akemi Takeoka Chatfield: School of Information Systems and Technology, Faculty of Engineering and Information Sciences, University of Wollongong, Wollongong, New South Wales, Australia 


\section{Introduction}

Volcanic activity and explosive eruptions are major hazards and risks to local residents. These eruptions impact local economies (Tobin and Whiteford 2002; Dominey-Howes and Minos-Minopoulos 2004), and disrupt critical infrastructure, the environment, and aviation on a large scale (Kueppers et al. 2006). Monitoring, communicating, and mitigating perceived risk of ongoing volcanic activities require close attention to social, environmental, and political issues of importance at the local, national, regional and global levels.

Despite operational volcano surveillance using meteorological satellite, thermal remote sensing and infrared camera technologies, predicting a volcano's hazardous activity and explosive eruption, with any accuracy, remains nearly impossible. Against this, volcanic hazards and risk literature identifies risk communication as critical (Tobin and Whiteford 2002; International Risk Governance Council 2005; Haynes et al. 2008; Leonard et al. 2008). However, systematic empirical inquiry regarding risk communication is lagging. Specifically, public perceptions of hazard, risk, and vulnerability can be more fully examined with emergent social media technologies, which have been used to transform traditional one-way government-to-citizen risk perception communications at the edge of disaster (i.e., geographically close to a hazard zone). In this research we are specifically interested in examining the emergent patterns of Twitter use of a particular hashtag \#sinabung during the unfolding volcanic eruptions. Previous patterns of government use of Twitter have been characterized by dynamic and multi-directional (government-to-citizen, citizen-to-government, and citizento-citizen) risk communications during the 2013 Hurricane Sandy (Chatfield et al. 2014) and the 2013 Oklahoma tornado (Chatfield and Brajawidagda 2014), in comparison to the more dominant use of e-government websites for disaster response coordination (Jaeger et al. 2007), which are often characterized by static and one-way government-to-citizen risk communications.

In this study we examine three inter-related research questions: (1) How does government use e-government websites and Twitter to communicate risk perceptions as the disaster dynamically unfolds? (2) How do citizens living near the edge of disaster and the public at safe distances use Twitter hashtags to communicate their risk perceptions and concerns? And (3) How does (or can) the effective use of Twitter hashtags influence citizen-centric e-governance in risk communication and external political efficacy (or perceived government responsiveness and perceived fairness of government procedures and outcomes), especially under the uncertain and dynamically changing disaster conditions? In this paper, we define e-government as the use of information and communications technology (ICT) for citizens to interact with their government. 
The use of Twitter and government websites will increase the communication flows to citizens, thereby, allowing them to update and improve information flows (Chatfield et al. 2013). We also believe that both platforms will have a positive impact on creating more citizen-centric e-governance, enabling citizens to become more involved in governance since information flows bi-directional.

This study examines these three research questions in the context of the disaster risk communications practice, during the Mt. Sinabung eruptions of February 2014 in Indonesia, which resulted in 16 deaths and continuous evacuations of 30,000 local residents. Some of the evidence presented in this paper show avoidable deaths of the curiosity-seekers (local students) and the return of the evacuees to safeguard their homes 1 day before the sudden eruptions, both occured despite the fact the government's own website retained the same highest alert status. The effects of the disaster were made worse by the lack of active and effective use of Twitter by government agencies in charge of risk communications and dissemination of such information to the public. Unlike the case of \#sandy, Indonesian disaster management agencies and government officials were much slower to effectively use \#sinabung created by Indonesian citizens. New communication tools such as Twitter are difficult to deploy during crisis communication, unless government agencies use such tools during ordinary times to engage with citizens (Chatfield et al. 2014). The Indonesian governments had a profound sense of detachment and disengagement from the enfolding crisis. Many Western newspapers, such as the New York Times, reported the confusion among the evacuees and the local citizens after the deaths of the students who went up to see the eruptions.

In this paper, we critically examined uses of e-government websites and social media, specifically Twitter, which facilitated or inhibited communications of risk perceptions by governments, the affected villagers, and the Indonesian public at large. We also examined the use of Twitter \#sinaung by citizens at the edge of disaster and citizens at safe distances to share their risk perceptions communications and concerns. Based on our key findings, we discuss the important roles of citizen-centric e-governance in overcoming time-critical multi-stakeholder risk communication challenges. Specifically, we discuss the potential beneficial impacts of implementing citizen-centric e-governance to improve external political efficacy in volcanic risk communications and empower citizens living at the edge of disaster to take appropriate action.

External political efficacy is defined as citizens' perceived government responsiveness to their demands and concerns (Parent et al. 2005; Anderson 2010) and as citizens' perceived fairness of government procedures and outcomes (Craig et al. 1990). An individual's external self-efficacy describes their ability to appraise what they are capable of performing and is said to be critical to know in hazard preparedness (Paton and Johnston 2001). Here the construct of citizen-centric 
e-governance aims to examine issues of external political efficacy more comprehensively by addressing not only citizens' perceived government responsiveness (Parent et al. 2005; Anderson 2010), but also citizens' perceived fairness of government procedures and outcomes (Craig et al. 1990). While the former has been found to influence citizens' trust in government, the latter seems to matter to citizens' perceived fairness of mass evacuation policies and logistics. There is little research that examines self-efficacy and volcanic disasters (Davis et al. 2005), with no research, that we are aware, examining this in the content of Twitter hashtags.

The structure of this paper is organized as follows: the next section presents our theoretical foundations of citizen-centric e-governance which will address external political efficacy more comprehensively. The third section presents a review of the literature on volcanic hazards and risk, disaster risk governance, and risk perception communication in a specific domain of disaster management in e-government research. In the fourth section, we present a specific disaster background on the February 1, 2014 eruption of Indonesia's volcanic mountain Mt. Sinabung. In the fifth section, we describe our research methods. In the sixth section, we present key research findings. In the seventh section, we discuss how our findings answer our three research questions. In this section, we also present our conclusions, including the research limitations of this study.

\section{Theoretical Foundation: Citizen-Centric E-Governance and Social Media}

The conception of citizen-centric e-governance articulated by Reddick (2011a) underscores the importance of empowering ordinary citizens to engage in democratic governance through the use of the Internet and other emergent social media network technologies such as Twitter. Citizen-centric e-governance represents a significant shift from prior e-government and public administration studies on "e-participation," "e-governance," or general use of the Internet in government. Citizen-centric e-governance provides the new ability to transform the government-to-citizen and the citizen-to-citizen relationships (Reddick 2011a; Linders 2012). It also provides networked ordinary citizens with the new virtual public spheres - for example social media networks in government through which they can influence (or even co-produce) innovations in political institutions, and hence help government move away from traditional supplyside, government-centric provision and delivery of public services, towards more demand-side, citizen-centric public services for greater citizen satisfaction and participation (Reddick 2005; Gauld et al. 2010; Reddick 2011b). Citizen-centric 
e-governance helps government more clearly understand citizens' diverse needs to facilitate government innovation and redesign e-government services: for example, one-way access to government data and policy information and two-way interaction and transaction with government (Reddick 2004).

The focus on citizen-centric e-governance in this article underscores the critical importance of government in creating greater government transparency and accountability through citizen engagement. Simultaneously, it recognizes the potential social and political power net-savvy ordinary citizens can provide government in achieving the goals of increased government transparency and external political efficacy through greater opening of government policy formulation and policy implementation. The theory of citizen-centric e-governance thus aims to explain the postulated theoretical relationships between external political efficacy and citizencentric e-governance. Here the theory of citizen-centric e-governance holds that citizens and their faith and trust in government will likely develop in response to their perceived fairness of political procedures and outcomes and their perceived government responsiveness. From this, the theory can explain how citizens, specifically net-savvy citizens, can influence public affairs and policy. Citizen-centric e-governance is the effective and collaborative use of information technology (IT) to enhance the ability of citizens to democratically engage with political discourse and decisionmaking and hence influence meaningful change in public policy decisions.

Social media refers to online tools that enable interactions between users and allows them to share information, opinions, and interests (Khan et al. 2014). Compared to traditional news media communication (particularly radio/TV, word of mouth, telephone), social media use by citizens can enable more citizen-centric e-governance. Traditional emergency management news has the government or press officer providing uni-directional release of information to the public as the event unfolds. Social media such as Twitter, provides for bi-directional information flows as the disaster unfolds (Palen 2008) and more recently, multi-directional disaster information sharing using Twitter hashtags. As example was the use of \#sandy during the 2012 Hurricane Sandy in the US (Chatfield et al. 2014). Twitter has become a dominant communication platform in social crisis situations (Oh et al. 2013). Social media enables citizens in disasters to actively engage in the creation or co-production of information, rather than being passive information consumers (Sutton et al. 2008). The use of social media platforms by citizens in Taiwan illustrated citizen-centric e-governance in action during the 2009 Hurricane Morakot. Its use first started organically among citizens and was then quickly adopted by the government as a communication and intelligencegathering platform during the response (Tseng et al. 2011). While an important issue with the use of interactive social media, such as Twitter, is that unreliable retweets may give incorrect information (Acar and Muraki 2011), social media is 
said to enhance situational awareness of victims during a crisis because the near instant updates that it provides (Yin et al. 2012).

\section{Literature Review}

\subsection{Volcanic Hazards and Risk}

The impact of volcanic eruptions on local communities has a long scholarly history (Annen and Wagner 2003). Volcanic eruptions can emit large amounts of rock fragments, pyroclastic flows and superheated ash plumes, large toxic clouds of sulphur dioxide $\left(\mathrm{SO}_{2}\right.$ ) gases, into the atmosphere (Loyola et al. 2008; Marti and Felpeto 2010). Volcanic eruptions are major natural hazards not only to public health of local residents, but also to the critical infrastructure, the local economy, and the aviation community and regional aviation safety (Thomas and Watson 2010). While volcanic studies have shown some progress towards understanding volcanic hazards and mitigating their risks (Fee and Matoza 2013), predicting its hazardous activity and explosive eruption, with any accuracy, remains nearly impossible, even with the use of meteorological satellite and groundbased thermal remote sensing and infrared camera technologies to monitor and sustain operational volcano surveillance. Research shows that volcanic threats are shaped by complex interactions between perception and risk associated with volcanic hazards, cultural beliefs and socioeconomic constraints (Lavigne et al. 2008). The typical responses to volcanic hazards are governed by managing communications of uncertainty (Barclay et al. 2008). The difficulty is that volcanic risk perception and communication research shows that not everyone living near a volcano will understand or accept the risks (Kelman and Mather 2008).

Table 1 below shows the previous 18 major explosive volcanic eruptions with the estimated human deaths of 1000 or more, during the period from 1900 to 2012 (http://www.emdat.be/search-details-disaster-list). Of the 18 eruptions, eight (or nearly 45\%) of them occurred in Indonesia, which claimed a total of 22,853 Indonesian lives. The large death toll is linked to volcanic areas often being fertile for farming and the population density near the fertile volcanic risk areas is high in developing countries. In contrast, some other countries, such as Iceland and Japan, which have been subjected to earthquakes and volcanic eruptions but have low population density nearest the volcanic risk areas, are not appearing in this Table. For the same period, there were 34 explosive eruptions, which resulted in the human deaths of at least 100. Of the 34 eruptions, the most recent eruption occurred in Mt. Merapi, Indonesia, in 2010, causing 322 human deaths. 
Table 1: Volcanic Eruptions: Database Research 1900-2012.

\begin{tabular}{llr}
\hline Year & Country, Volcano & Number of Deaths \\
\hline 1902 & Martinique, Mt. Pelee & 30,000 \\
1902 & Guatemala, Mt. Santa Maria & 6000 \\
1909 & Indonesia, Mt. Kelud & 5500 \\
1911 & Philippines, Mt. Taal & 1335 \\
1919 & Indonesia, Mt. Kelud & 5000 \\
1929 & Guatemala, Mt. Santiaguito & 5000 \\
1930 & Indonesia, Mt. Merapi & 1369 \\
1931 & Indonesia, Mt. Merapi & 1300 \\
1949 & Colombia, Mt. Purace & 1000 \\
1949 & Mexico, Mt. Paricutin & 1000 \\
1951 & Indonesia, Mt. Merapi & 1300 \\
1951 & Papua New Guinea, Mt. Lamington & 3000 \\
1963 & Indonesia, Mt. Agung & 1584 \\
1966 & Indonesia, Mt. Kelud & 1000 \\
1982 & Mexico, Mt. El Chichon & 17,000 \\
1985 & Colombia, Mt. Nevado Del Ruiz & 21,800 \\
1986 & Cameroon, Mt. Lake Nyos & 1746 \\
2006 & Indonesia, Mt. Merapi & 5800 \\
\hline
\end{tabular}

Source: EM-DAT (2012).

While natural hazards cannot be prevented, governments can often mitigate disaster risk by providing timely and actionable information using early detection warning systems. Disaster early detection and warning systems provide this important information (Chatfield et al. 2013), through authorized government agencies, to enable citizens exposed to hazard to take effective action, avoid or reduce their risk, and prepare for effective response (http://grid2.cr.usgs.gov/ siouxfalls/publications/Early_Warning.pdf).

\subsection{Disaster Risk Governance}

The impact of large, regional natural disasters, such as 2004 Indian Ocean Tsunami, 2005 Hurricane Katrina, 2010 Haiti Earthquake, 2011 Great East Japan Earthquake, and 2012 Hurricane Sandy, has extensively overwhelmed the response capacity of local government agencies (Chatfield and Brajawidagda 2014; Chatfield et al. 2014).

There has been a widespread recognition, within the public sector, the private sector, academia, the media, and society at large, that the complexity 
and interdependence in disaster risk issues made it increasingly more difficult for governments and communities to develop and implement effective disaster risk governance strategies (International Risk Governance Council 2005). Against this, the International Risk Governance Council (IRGC) has developed a comprehensive Disaster Risk Governance Framework (see Figure 1), which has been fully or partially adopted in a number of countries worldwide.

The framework identifies five phases, of which the final phase, Communication, is "of the utmost importance" because effective communication is the key to creating public trust in disaster risk management (International Risk Governance Council 2005: p. 14). It must be noted that while the construct of Communication is identified as the fifth phase, effective communication is critically important in performing and managing efficiently and effectively the preceding phases in the Assessment Sphere and Management Sphere.

The research in this paper is particularly concerned with the actual use and impact of Twitter in the interface between Risk Appraisal and Communication. As Figure 1 shows that the Risk Appraisal phase processes consist of risk assessment and concern assessment as a guide to our research. While the social science conceptions of risk assessment are widely known in disaster management communities (Carlino et al. 2008), the concern assessment needs some explanation. The concern assessment consists of exploring and identifying heterogeneous risk perceptions held by different stakeholders, indicating that, for example, risk perceptions held by a given government agency in Jarkata may not be the same as those held by villagers living near the volcanic mountain or tourists visiting Indonesia who are curious about an enfolding disaster event.

Extant government reports on the 2005 Hurricane Katrina (Government Accountability Office 2006a,b) and the 2009 Victorian bushfires in Australia (Victorian Bushfires Royal Commission 2010) provide clear evidence that disaster communication governance deficits contributed to the slow disaster response and recovery operations and the erosion of public trust in government disaster management.

\subsection{Risk Perception Communications}

Risk perceptions are how the public understands threats and protects against them (Perry and Lindell 2008). The important role played by effective risk perception communication in volcanic hazards and risk literature is consistent with that found in the tornado hazards and risk literature (Bird et al. 2009). Research shows that the most effective response during a volcanic crisis not only depends upon the public's knowledge of the emergency plan, but their perception of the 


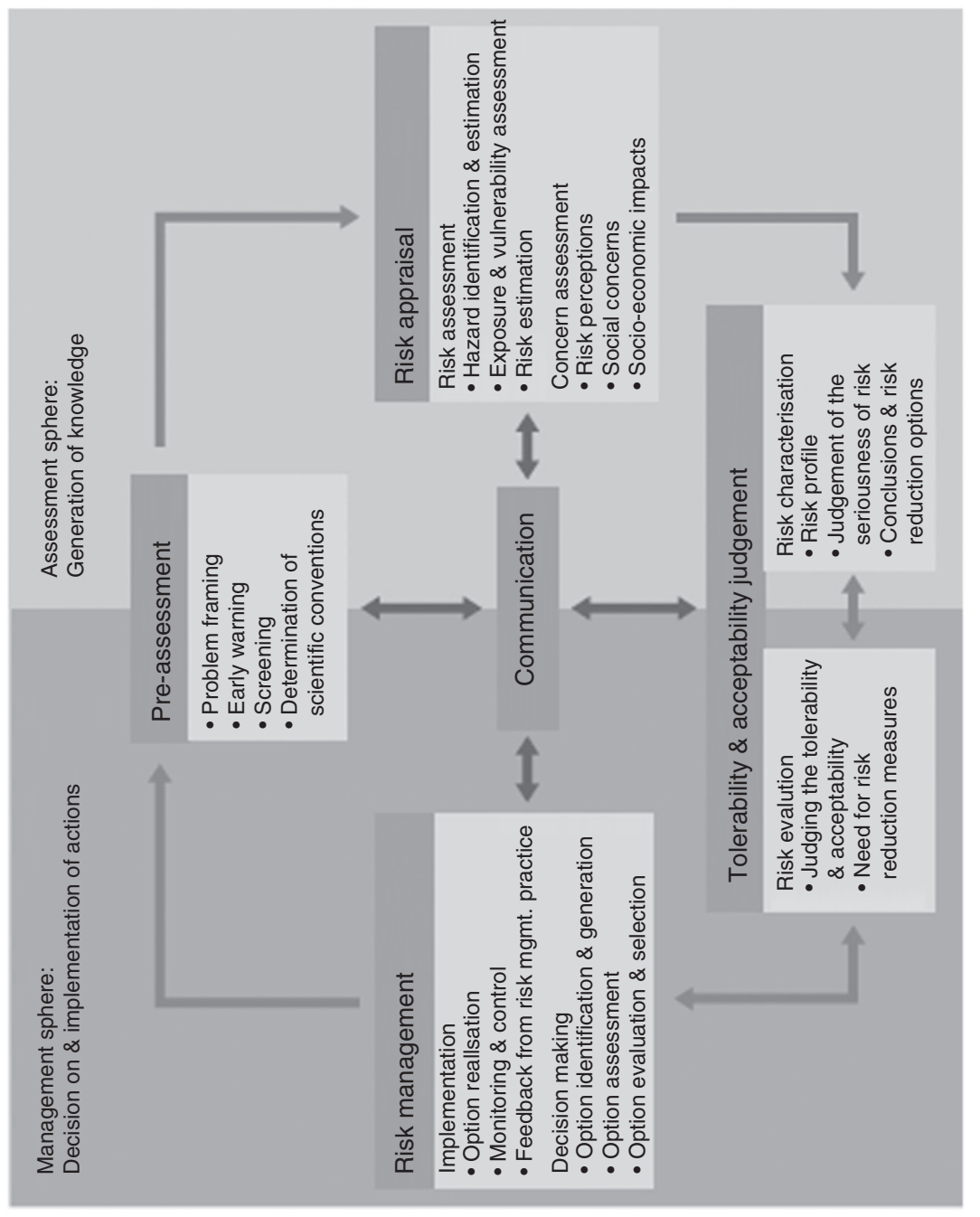

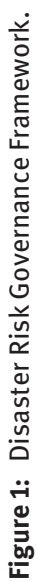


risk of this hazard to them (Bird et al. 2009). The current literature on volcanic risk management still often focuses on hazard prevention and mitigation and tends to discuss less the important social context of risk perception communication (Gaillard 2008). In order to understand volcanic risk perceptions, we must understand the broader social environment (Gaillard and Dibben 2008). Research shows that the public's perception of risk has been linked to proximity to the source of a hazard, perceptions of the likelihood of future disasters, and past experience in disasters (Gregg et al. 2004).

In looking at trust in government, which is related to higher external political efficacy, research on volcanic risk shows that scientists and emergency responders were trusted the most, while government is the least trusted (Haynes et al. 2008). In a review of the literature, public participation is the most effective means to create greater awareness of potential disaster risks, to enhance trust in public authorities, and to encourage citizens to take on more personal responsibility for disaster preparedness and planning (Wachinger et al. 2013). There are various models that look at hazard risk for members of a community, with demographic factors such as age, gender, and race providing some of the best predictors (Lindell et al.2009). Research shows that those living close to volcanic risk, especially the young, are more aware of the risks, most likely through education programs (Carlino et al. 2008). For mitigating hazard risk in a volcanic crisis, research indicated that it is important to have greater civic engagement of citizens (Paton et al. 2008). A low risk perception may lull residents into a false sense of security and cause them to underestimate the threat level. Much of the research focuses on residents and their adjustments to hazards as recommended by government (Terpstra et al. 2009). This study focuses on risk perceptions of citizens - both citizens at the edge of disaster and the public at safe distances.

In prior research on the use of Twitter for crowd sourcing examining tornado risk information (Chatfield and Brajawidagda 2014) indicates that tornadoes even under favorable climate conditions are difficult to detect and predict accurately even with advanced network of integrated NEXRAD (Next Generation Weather Radar) WSR-88D (Weather Surveillance Radar - 1988 Doppler) (Bieringer and Ray 1996). Given such short warning lead times, prior research on tornado warnings even argues that early warnings which do not reach the citizens and motivate their appropriate responses are not very valuable, even if they are accurate and timely (Doswell et al. 1999). Citizens tend to not take appropriate action before and during tornados despite the government warnings. (Doswell et al. 1999).

Examining the volcanic hazards and risk literature found evidence for variances in the levels of perceived risk among the community survey respondents in the contexts of the 1995 Ruapehu eruption (Johnston et al. 1999) and ongoing volcanic hazard of Mt. Tungurahua in Ecuador (Tobin and Whiteford 2002). This 
evidence is consistent with the survey results found on the variances in disaster risk perceptions and misperceptions among the US government survey participants in the e-government literature (Rahm and Reddick 2011). These consistent findings from the different disciplines suggest the challenge in clearly communicating disaster risk perceptions not only among government cross-jurisdictions, but also between the government and citizens. Prior e-government research suggests important factors that can improve external political efficacy, which are citizens' trust in government (Parent et al. 2005), management capacity (Reddick 2009), and citizen-centric e-governance (Reddick 2011a).

From our explained theoretical foundations of citizen-centric e-governance, one can note that volcanic eruptions are hazardous and risky to communities. Risk governance and risk management are undertaken to make these communities safe. One aspect of good disaster risk governance and disaster management is a well informed and risk aware community who trust, understand, and act on early warnings and risk perception communications of public authorities. Perception of volcanic risk is influenced by many factors including trust and awareness. Therefore, good governance will find ways of effective and trustworthy engagement and communication with communities. Lastly, citizen-centric e-governance is one new mechanism that is under explored but potentially relevant in this case of Indonesia's Mt. Sinabung volcanic eruption.

\section{Disaster Background}

Geographically, Indonesia consists of 13,466 islands, including 5 big islands (http://www.bakosurtanal.go.id/). The nation has 137 active volcanoes with more than 5 million people living at the edge of these volcanic hazards and potential disaster risk areas (http://id.wikipedia.org/wiki/Gunung_Sinabung).

\subsection{Mt. Sinabung Eruptions}

Indonesia's Mt. Sinabung (elevation $2460 \mathrm{~m}$ ) is marked by the brown locator, A, on Figure 2 below. It is located in Karo Regency (or local government jurisdiction), North Sumatra Providence (or state government jurisdiction), which was very close to the epicenter of the 2004 mega-earthquake that triggered the Indian Ocean Tsunami. It last erupted in 2010. More recently it has been erupting superheated clouds of ashes daily from November 1, 2013 to February 28, 2014, which necessitated government mandated evacuations of more than 30,000 local residents living within the $5 \mathrm{~km}$ of the volcano to safe evacuation shelters 


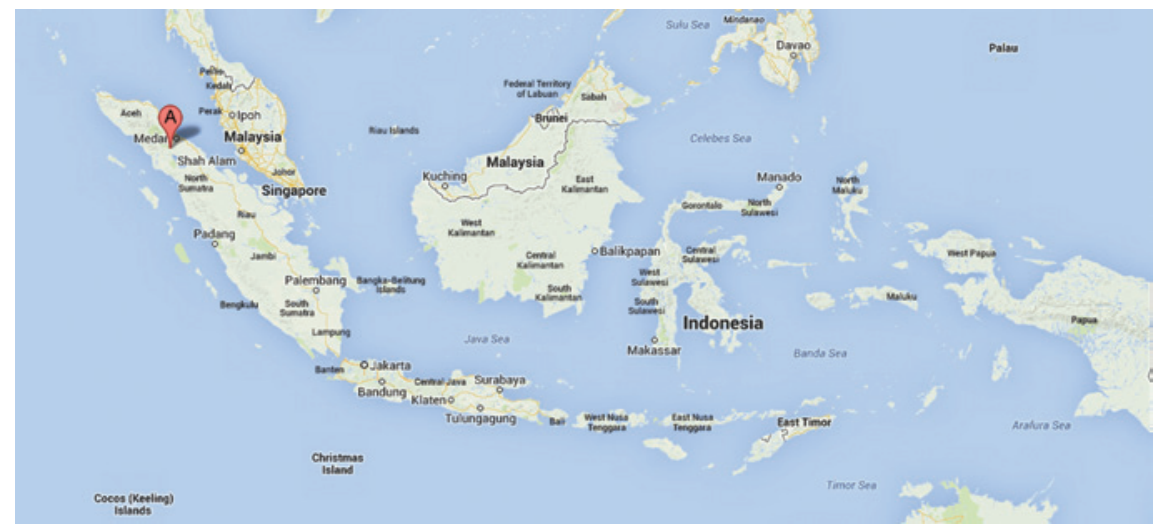

Figure 2: Mt. Sinabung on a Map of Indonesia.

down below (Pathon 2014; http://www.thejakartapost.com/news/2014/02/04/ sinabung-not-national-disaster-bnpb-says.html; http://www.bnpb.go.id). But on February 1, 2014, Mt. Sinabung explosively erupted with pyroclastic flows, superheated clouds of ashes and gases. This explosive eruption claimed the death tolls of 16 local residents and students who were found within the $5 \mathrm{~km}$ off-limits evacuation zone (http://www.thejakartapost.com/news/2014/02/04/sinabungnot-national-disaster-bnpb-says.html; http://www.bnpb.go.id).

Figure 3 below shows a night-time photo of the continuous explosive eruptions of Mt. Sinabung on February 1, 2014.

\subsection{Indonesia's Volcanic Risk Management Agencies}

At the national government level in Indonesia, the government agency responsible for monitoring and assessing volcanic hazards and disaster risk mitigation is the Centre for Volcanology and Geological Hazard Mitigation (PVMBG). On a regular basis, the PVMBG conducts a series of research and scientific observations on the seismic and volcanic activity to issue scientific reports, volcanic activity alerts and volcanic eruption warnings to the President's Office, the National Disaster Management Agency (BNPB), local disaster-related government agencies, and local and provincial governments, where active volcanoes are located within their jurisdictions.

The PVMBG uses four levels of alerts on volcanic hazards and risk (see Table 2) to communicate its risk perceptions and calls for associated actions to other government agencies responsible for disaster management (http://www. vsi.esdm.go.id/). 


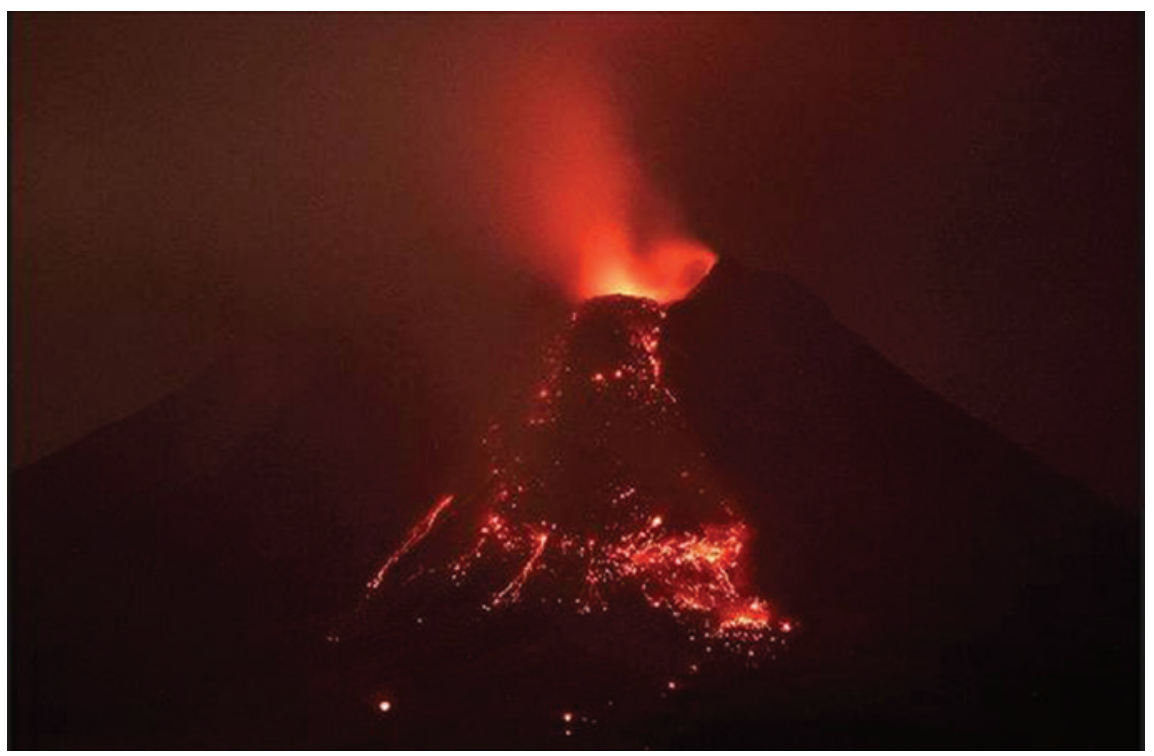

Figure 3: The Explosive Eruption of Mt. Sinabung on February 1, 2014.

Table 2: Four Alert Levels on Volcanic Hazards and Risk.

\begin{tabular}{lll}
\hline Status & Meaning & Associated Actions \\
\hline I & - None of pressure magma indication & - Routine observation \\
Normal & - Low-level volcanic activities & - Survey and investigation \\
II & - Slight higher indication of magma & - Risk assessment \\
Vigilant & - Increasing seismic and volcanic activities & \\
& - Increasing hydrothermal and tectonic & \\
& activities from the normal level. & \\
III & - Further increased seismic activities & - Limited socialization in \\
Alert & - All data on seismic activities have been & hazardous areas \\
& Showing likely or possible eruption. & - Readiness for evacuation \\
& - If this trend continues, then eruption & \\
IV & might be in 2 weeks. & \\
Warning & - Volcano is going to erupt or is erupting. & - Actual evacuations from \\
& - Eruption will happen in 24 h. First eruption will be starting with ashes & \\
& and gases. & \\
\hline
\end{tabular}

With every change in the level of alertness, it issues a formal and scientific risk communication to the National Disaster Management Agency (BNPB). However, the PVMBG's risk communication is not aimed to inform the public 
directly. Its scientific and technical risk information content makes it almost impossible for the public, including those who are highly educated, to fully understand the risk communication. PVMBG publishes risk perceptions using the categories presented in Table 2, which are viewed by other central government agencies and mass media. Then BNPB communicates with citizens since PVMBG is a scientific body and its specialized language, which is difficult for the average citizen to understand given the scientific language of the documents. Instead, the risk communication is used by disaster management agencies such as BNPB to perform their comprehensive disaster management cycle activities: Preparedness, Response, Recovery and Risk Mitigation. Unlike the PVMBG, the BNPB is legally mandated to communicate its risk perceptions at the edge of disaster to the vulnerable communities, as well as the media and the general public.

\section{Research Methods}

\section{1 e-Government Website Analysis}

In order to answer the first research question raised in this article: (1) How does government use e-government websites and Twitter to communicate risk perceptions as the disaster dynamically unfolds? We first examined and identified relevant disaster management agencies' official websites at all levels. Specifically for volcanic hazards and risk communication, we found two national-level government agencies responsible for hazards and risk assessment and risk communications: Centre for Volcanology and Geological Hazard Mitigation (PVMBG) (www. vsi.esdm.go.id) and National Disaster Management Agency (BNPB) (www.bnpb. go.id). Next, we performed content analysis of these two agencies' e-government websites (in Indonesian) through the use of two independent reviewers; both of whom are Indonesian Ph.D. students studying in Australia. Specifically, we gathered data on the government agencies' risk perception communications on Mt. Sinabung eruptions.

This website content analysis approach is appropriate for this research, since the government websites are formally moderated by the government agencies and the website content represents the government-centric risk communications. It would enable us to understand how these government agencies responsible for hazards and risk communications actually communicated their perceived risks of the ongoing volcanic hazards and risk to the vulnerable local residents, citizens and society at large. Finally, we also examined the website risk communication 
content at the local government level, with special attention paid to that of the Karo Providence government where Mt. Sinabung is located.

\subsection{High-Level Twitter Use by Indonesian Citizens}

With 271 million monthly active users and 500 million tweets sent per day worldwide in 2014, Twitter supports 35 different languages (Twitter 2014). While the US still clearly dominates the Twitter market today, the use of Twitter outside the US has shown significant growth over recent years (Sysomos 2010). The Indonesian Twitter market is remarkably large with 9 million Indonesian users on Twitter, and Jakarta's Twitter users post $2.4 \%$ of the 10.6 billion tweets annually worldwide. This high level of Twitter adoption and diffusion in Indonesian society is not surprising given Indonesia's large population of over 240 million vis-à-vis 300 million in the US (Sadowski 2014). Indonesia was Asia's leader with 5,616,000 Twitter users based on the 2009 data (Sysomos 2010). More recently, Indonesia ranks fifth in the world in the number of active users on Twitter, only behind the US, Brazil, Japan, and the UK (Semiocast 2012). It is noteworthy that, the study by Semiocast, a market and opinion research company, shows that Indonesia has registered the second largest surge in terms of the number of the new Twitter accounts created during the first half of 2012, with the US showing the largest gains. The same study also shows that Jakarta, the capital of Indonesia, ranks the first on the list of the top 20 cities on Twitter in terms of the number of posted tweets, ahead of other mega cities of Tokyo, London, São Paulo, and New York (Semiocast 2012).

As we clearly indicated earlier, the risk information flows from the only official source in Indonesia, that is, PVMBG. Certainly, national mass media and local radio sources have an impact on information dissemination to citizens. Given the information flows are very structured and hierarchical in Indonesia, the use of Twitter plays a significant role providing bottom up information from citizens. Here the volume of Twitter communications are not an issue; but as a complementary source of risk perceptions. As we pointed out earlier, risk perceptions vary among different stakeholders. Even within the single government organization, contradictions were observed.

\subsection{Social Network Analysis}

Social network analysis (SNA) has been used in e-government (Chung and Chatfield 2011), early disaster warnings and disaster preparedness (Chatfield 
et al. 2013; Chatfield and Brajawidagda 2014) and disaster response (Cheong and Cheong 2011; Chatfield et al. 2014). The utility of SNA is to enable researchers to uncover the underlying (dynamically) changing structure and connectivity of ad hoc online social networks through an examination of nodes and links between those nodes. The SNA can help with understanding roles of central big nodes with highly connected links in exerting social and political influence within the online social networks (Chatfield and Brajawidagda 2012; Chatfield et al. 2014). Salient information and knowledge, such as interrelationship (Bales et al. 2008; Ying 2010), effective communication (Cheong and Cheong 2011), and behavior of a network (Baggio 2008) can be extracted for further analysis through the analysis of nodes and their inter-relationships. In the SNA, visualization of the structure and connectivity along the spatial and temporal dimensions is important for generating insights and predictions of a social phenomenon such as risk perception communications among stakeholders. Therefore, a social network graph is used to capture and represent a social network composed by nodes and links. More often than not, nodes represent actors-either individuals or organizations -within a social network, whereas links represent relationships, connections, information flows, communications or intelligence exchanges among the actors. A social network graph enables us to visualize big data and complex information flows for a general overview and initial interpretations.

We collected the specific theme tweets using \#snabung since we are specifically interested in the tweet content related to the eruptions. Our data collection period was from November 1, 2013 to February 28, 2014, which includes the February $1 \mathrm{Mt}$. Sinabung eruption. Python programming language is used to search and download tweets from topsy.com website, a Twitter certified social search and analytics company which maintains a comprehensive index of user-generated social media content. Excel spreadsheets are used to analyze the download data. With these software tools, the salient node level and network level measurements of ad hoc online social networks were computed from the existing nodes. For example, we calculated node level measurements in this study: big nodes as nodes with a large number of followers and in-degree centrality as the number of nodes connected to a central node. We also calculated network level measures such as density, diameter, weakly connected components, strongly connected components and average path length. The size of a social network is determined by the number of nodes. The strength or weakness of network connectedness is represented by the number of the links between the nodes. The density of a social network refers to the degree of dyadic connections in a social network, indicating how fully the network is inter-connected. The diameter of a network is the largest distance of any dyadic pair of nodes in the network. While the weakly connected component represents the number of one-way communications among 
the nodes, the strongly connected component represents the number of the nodes with two-way communications (Chatfield et al. 2014).

In order to answer the first and second research questions, we downloaded 19,394 tweets with the use of software tools which crawl, search, and randomly capture the posted tweet data from the tweet database of Topsy.com. In this study we specifically focused on a social network analysis of tweets posted by Twitter users via the use of a specific hashtag \#sinabung. Hashtag use enables efficacy in searching a specific topic of interest among the big tweet data on Twitter. Twitter promotes the use of specific hashtags to optimize search strategies for finding specific topics of shared interest. In our study, the hashtag \#sinabung indicates specific topic interests related to Mt. Sinabung eruptions. Our tweet data collection was conducted through searching the tweet database of Topsy.com, a third party, since the Twitter policy limits the volume of tweets for download. The tweet data collection period was for the duration of 1 month; from January 4, 2014 to February 4, 2014, inclusive of the date of the Mt. Sinabung eruptions. During the data collection period, 79,000 tweets were posted using \#sinabung. Hence, we strategically focus on \#sinabung users - those Twitter users who are particularly interested in the discourse on volcanic eruptions at this Indonesian mountain rather than \#worldcup or other topical hastags.

The number of tweets we analyzed (19,394 tweet dataset) represents $24 \%$ of the 79,000 tweets posted, with the \#sinabung embedded in a tweet, during the period of our tweet data collection. Like survey research and case study research, the optimal research design is to randomly (in the case of survey research) or strategically (in the case of theory development case study research) draw a sample of sufficient size relative to the population size, when the study of the entire population is not economical or feasible due to research resource constraints.

Of the 19,394 tweets collected, we identified 5145 unique Twitter account holders (individuals or organizations officially registered their unique accounts with Twitter) who were using the specific hashtag \#sinabung. This implies that on average the 5145 Twitter hashtag users posted approximately 3.8 tweets during 1 month, the period of our data collection period. We define perceived active \#sinabung users (or big nodes) by measuring the number of their tweet followers. While the larger number of followers does not always indicate the level of social influence they exert in their online social networks formed by the hashtag users, the perceived active users can be used as a proxy for their perceived contribution to the Twitter-mediated risk.

Moreover, of the 5145 unique \#sinabung users, we found that 4036 of them (or 78\%) had voluntarily disclosed the geographical location information in their Twitter profiles. This geographical location information refers to where their Twitter account was registered in their Twitter profiles, not the actual locations 
where they posted their \#sinabung tweet. Of the 4036 \#sinabung users' disclosed locations, we could accurately identify only 2941 discernible geographical locations. Some unidentifiable location information was found, including "in your heart," "on earth," "in a beautiful country" or "21 Melati Street." Of the 2941 \#sinabung users, 2745 (or 93\%) of them are from Indonesia, whereas the rest (196 or 7\%) are distributed across US, Canada, Europe (UK, Scotland, and Netherland), Asia (Japan, Malaysia, Thailand, and Philippines), and Australia. Therefore, for this research we analyzed 2745 (or 53.4\%) \#sinabung users' disclosed geographical locations. Of the 2745 Indonesian \#sinabung users, 532 \#sinabung users are distributed in the North Sumatra Providence where Mt. Sinabung is located.

\section{Findings: Risk Perception Communications}

In this section, we answer the first two research questions raised in this article. In answering the first question we describe our key findings on government risk communications via e-government websites and via Twitter. In answering the second question, we first present our key findings on risk perception communications via Twitter's user-generated special hashtag \#sinabung among citizens at the edge of disaster within the geographical proximity to the volcanic eruptions. Next we present our key findings on risk perception communications via \#sinabung by the Indonesian public.

\subsection{Government Risk Communications via E-government Websites}

The PVMBG website was updated daily in November 2013 to show some significantly increasing geological activities at Mt. Sinabung. However, the government risk perceptions radically changed since 10 am (local time) on November 24, 2013. Table 3 below shows this shift on the third row (in bold font for emphasis). It shows that the level of alertness status of Mt. Sinabung was elevated to the highest level IV (red level). This risk communication signals the need to execute the full evacuation within some high-risk geographical areas. The evacuation of approximately 30,000 local residents was governed and managed by the BNPB (see Background section on BNPB).

The website indicates the evacuation of four regencies to safe evacuation shelters. The four regencies encompass fifteen villages and two sub-villages within the $5 \mathrm{~km}$ radius of the volcano, which was declared by Indonesian government as 
Table 3: Mt. Sinabung Activity Chronologies.

\begin{tabular}{|c|c|c|}
\hline Date (dd/mm/yy) & $\begin{array}{l}\text { Status of } \\
\text { Alertness }\end{array}$ & Policy \& Government Action \\
\hline$\sim 3 / 11 / 13$ & Level II & $\begin{array}{l}\text { - The off limits evacuation zone is } 3 \mathrm{~km} \text { radius of the } \\
\text { volcano top. } \\
\text { - The local villagers are permitted to do normal activities } \\
\text { within the off limits zone. }\end{array}$ \\
\hline $3 / 11-13$ & $\begin{array}{l}\text { level II to } \\
\text { level III }\end{array}$ & $\begin{array}{l}\text { - Limited socialization in hazardous areas } \\
\text { - Readiness for evacuation }\end{array}$ \\
\hline $24 / 11 / 13$ & $\begin{array}{l}\text { Level III to } \\
\text { Level IV }\end{array}$ & $\begin{array}{l}\text { - Full evacuation ordered } \\
\text { - Off limits zone escalated to } 5 \mathrm{~km}\end{array}$ \\
\hline$\sim 31 / 1 / 14$ & Level IV & $\begin{array}{l}\text { - Evacuees remain in safe shelters } \\
\text { - Off limits zone remains } 5 \mathrm{~km}\end{array}$ \\
\hline $31 / 1 / 14$ & Level IV & $\begin{array}{l}\text { - Local residents ( } 13,828 \text { evacuees) from } 16 \text { villages } \\
\text { farther outside the } 5 \mathrm{~km} \text { off limits zone from the volcano } \\
\text { top are allowed to return to their homes. }\end{array}$ \\
\hline $1 / 2 / 14$ & Level IV & $\begin{array}{l}\text { - Some evacuees and local government officials may } \\
\text { be allowed to briefly return to the off limits zone for the } \\
\text { inspection of damage to their houses. }\end{array}$ \\
\hline $1 / 2 / 14$-current & Level IV & $\begin{array}{l}\text { - Government agencies are concerned with the growing } \\
\text { number of evacuees in the safe shelters. }\end{array}$ \\
\hline
\end{tabular}

off limits to the local villagers, tourists and other visitors. However, the website as of January 31, 2014, 1 day prior to the Mt. Sinabung eruptions, shows that those who live outside the $5 \mathrm{~km}$ mandatory evacuation zone could return to their home and resume their normal living but still must respect the off limits zone. Furthermore, the same government website informs, on the day of the eruptions, that some evacuees and local government officials may be allowed to briefly return to the off limits zone for the inspection of damage to their houses. It must be noted that these two risk communications to the public were posted while the alertness status of Mt. Sinabung (elevated to the Level IV) remained in effect.

\subsection{Government Risk Communications via Twitter}

As discussed earlier in our Background section, the BNPB is responsible for communicating information about hazards and disaster risk, informing the current status of the volcano directly to the public via its e-government website and via its news release to the mass media. As discussed earlier, it totally depends on the PVMBG risk assessment to inform the public about the latest volcanic hazards 
and risk of Mt. Sinabung. More recently, the BNPB adopted risk perception communications via Twitter.

For example, a tweet was posted by the BNPB on January 31st, 2013 - 1 day before the February 1 explosive eruption - to remind the public that the $5 \mathrm{~km}$ radius off limits evacuation zone remains in effect. In the same tweet, however, the BNPB declares no significant increase in risk from Mt. Sinabung eruption within the $5 \mathrm{~km}$ radius evacuation zone. In another tweet issued at $2 \mathrm{pm}$ on January 31, 1 day before the volcanic eruption, the BNPB communicated that those who live further down on the mountain and outside the $5 \mathrm{~km}$ radius evacuation zone, except the except the village of Kutatengah, can return to their homes. As the BNPB tweeted the website news on January 31, 2014, as many as 13,828 evacuees from Mt. Sinabung were returned to their homes.

Importantly, based on our analysis of the tweets in this study, there is no evidence for bi-directional or multi-directional risk communications using \#sinabung on the volcanic hazards and risk among the BNPB, the PVMBG, the local governments, the affected local residents, the local communities nearest the affected mountain villages, and the public. Rather it seems that the BNPB used Twitter to maintain traditional top-down and one-way disaster risk communications. The government did not use a hashtag to communicate about the disaster and did not monitor, from what we are aware, the \#sinabung hashtag created by citizens. In contrast, prior study on the use of Twitter during and in the immediate aftermath of the 2012 Hurricane Sandy in the US has documented evidence for the active multi-directional conversations among the government agencies and the public on collaborating together to mitigate the devastating disaster impacts to the affected citizens and communities, such as addressing risk perceptions and social concerns about the availability of warm shelters for the affected (Chatfield et al. 2013).

\subsection{Citizens' Risk Perception Communications via Twitter}

In order to answer the second question we raised in this research, we first identified the geographical locations of the 532 networked citizens living at the edge of disaster in North Sumatra Province. They communicated using the \#sinabung to respond to the unfolding disaster. In Figure 4, we mapped the geographical distribution of the \#sinabung users within the local area impacted by the explosive eruption of Mt. Sinabung. Figure 4 shows Mt. Sinabung and the affected area marked by the red, orange and yellow circles, whereas the \#sinabung users are shown with the light green circle. Again, the relative size of the light green circles corresponds to the number of the \#sinabung users: 461 from the capital of the 


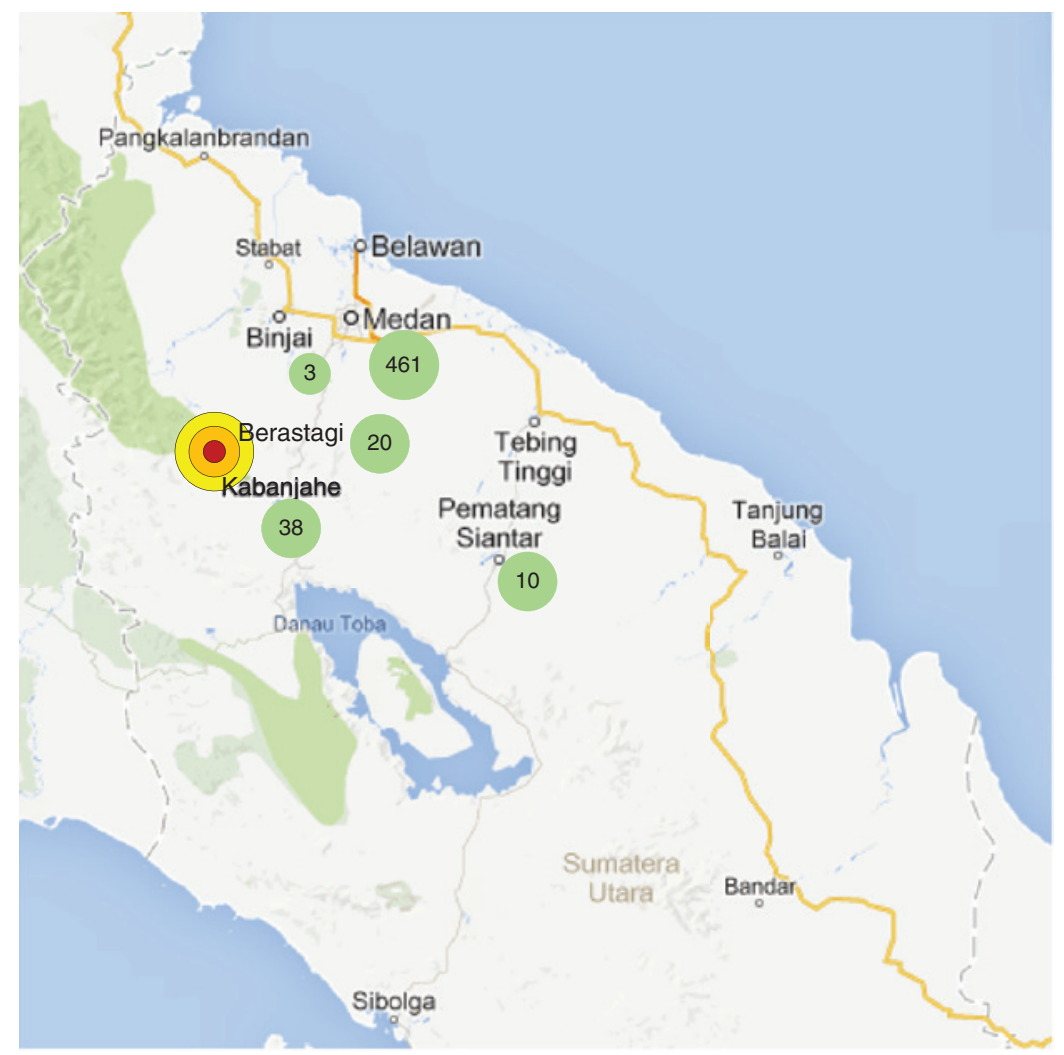

Figure 4: \#sinabung Users at the Edge of Disaster Close to Mt. Sinabung Eruptions.

Province, Medan; 38 from the nearest city, Kabanjahe; 20 from Berastagi; 10 from Pemaatang Siantar; and 3 from Binjai.

\subsubsection{Risk Perception Communications via \#sinabung by Citizens Living at the Edge of Disaster}

In order to answer the second research question, we performed a social network analysis on this online social network triggered and formed by the 532 \#sinabung users from North Sumatra Province where Mt. Sinabung had been predicted to erupt since 2013. They communicated using the \#sinabung to respond to the unfolding disaster. Our analysis focused on uncovering the structure and connectivity among this online social network. 
Figure 5 shows a social network graph. It provides us with the visualization of this online social network, which showed their risk perception communication flows. Figure 5 shows ten colored circles (ranging from yellow to brown) in different sizes to identify ten big nodes. The circle size in social network graph is determined by the number of (ten largest) followers who followed the ten big nodes' tweets with the embedded \#sinabung during the 1-month tweet data collection; from January 4, 2014 to February 4, 2014. Kumpulanmedan (shown by the brown circle), a known buzzer (a buzzer tweets for money) had the largest followers. All ten nodes are Indonesian individuals or organizations. In other words, the bigger node size indicates that the node has a greater number of followers. Figure 5 also identifies Karo_News, Kumpulanmedan, and Medanupdate in larger font size. The larger font size is determined by the higher value of in-degree centrality,

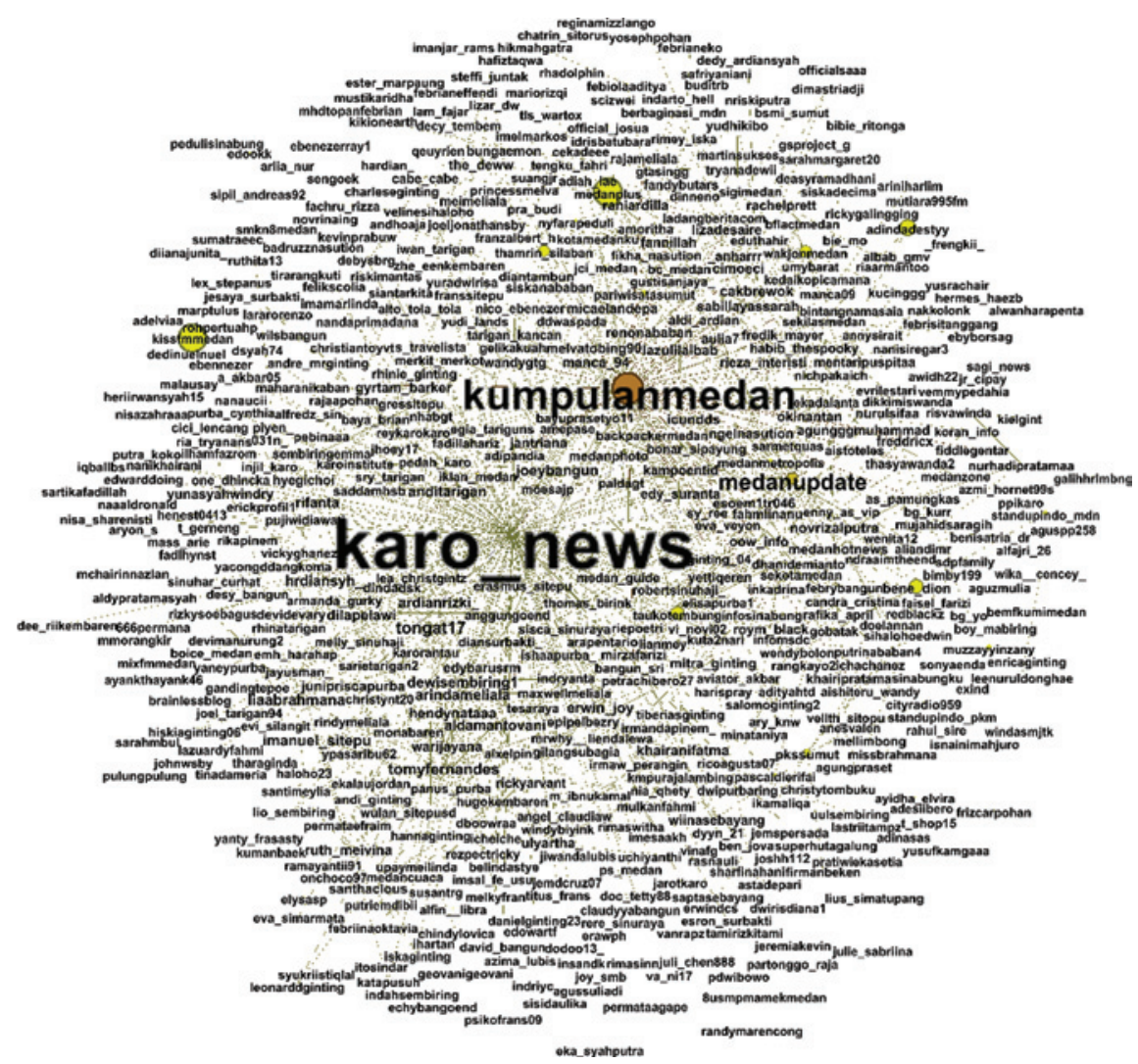

Figure 5: A Social Network Graph of the Online Social Network Formed by 532 \#sinabung Users from North Sumatra Province. 
a node level measurement in this social network diagram. In other words, the larger font size of nodes indicates that they are central nodes from which communication links (shown by dotted lines) emanate to greater numbers of other nodes in the social network graph. We found that Karo_News was the dominant central node with greatest connections with both other nodes of various sizes. The bigger font size indicates that the node has a greater in-degree follower. In-degree is a measure used in social network analysis to identify a given node (e.g., a Twitter account holder, a citizen or a government agency) is a core (or a star) defined by many more communicative or productive activities or a peripheral defined by less or no such activities. Higher value refers to the former and the lower value the latter. Value is greater connections with other nodes in the online social network. Overall, Karo_News had the greatest in-degree follower value in the online social network, whereas Kumpulanmedan had the biggest number of followers.

It must be noted that while all of the three central nodes are Indonesian organizations, none of them are governments at any levels. This indicates that local governments at the edge of disaster as well as national and state governments at safe distances from the disaster were not leading risk perception communications using Twitter as the long predicted and expected explosive volcano eruptions were unfolding.

Table 4 below further affirms our observation that the government agencies are not active \#sinabug users. The list of the top 15 active \#sinabung users is

Table 4: Top 15 Users Ordered by In-Degree Follower.

\begin{tabular}{llrrrl}
\hline No & Twitter User & $\begin{array}{r}\text { Number of } \\
\text { Followers }\end{array}$ & $\begin{array}{r}\text { Number of } \\
\text { In-degree } \\
\text { Followers }\end{array}$ & $\begin{array}{r}\text { Followers: } \\
\text { In-degree }\end{array}$ & Description \\
Followers Ratio & \\
\hline 1 & karo_news & 5240 & 213 & $4.1 \%$ & Mass Media \\
2 & kumpulanmedan & 40,617 & 129 & $0.3 \%$ & Buzzer \\
3 & medanupdate & 14,966 & 54 & $0.4 \%$ & Buzzer \\
4 & tongat17 & 725 & 23 & $3.2 \%$ & Citizen \\
5 & tomyfernandes & 452 & 16 & $3.5 \%$ & Citizen \\
6 & liaabrahmana & 639 & 14 & $2.2 \%$ & Citizen \\
7 & imanuel_sitepu & 475 & 13 & $2.7 \%$ & Citizen \\
8 & arindameliala & 628 & 12 & $1.9 \%$ & Citizen \\
9 & joeybangun & 399 & 11 & $2.8 \%$ & Citizen \\
10 & erwin_joy & 302 & 10 & $3.3 \%$ & Citizen \\
11 & anditarigan & 506 & 10 & $2.0 \%$ & Citizen \\
12 & dilapelawi & 421 & 10 & $2.4 \%$ & Citizen \\
13 & aldamantovani & 233 & 10 & $4.3 \%$ & Citizen \\
14 & khairanifatma & 305 & 9 & $3.0 \%$ & Citizen \\
15 & rifanta & 456 & 9 & $2.0 \%$ & Citizen \\
\hline
\end{tabular}


showed in Table 4, who are ordered by their in-degree follower value. Of the top 15 active \#sinabung users with the greatest in-degree follower, only @karo_news, @kumpulanmedan and @medanupdate had more than 1000 followers. This is not surprising since the online social network has only 532 unique \#sinabung users. Other relatively big nodes, such as @medanplus, @adindadestyy, @benedion, and others, are not listed in Table 5 because they had much less in-degree follower values. In term of in-degree follower, @karo_news and @kumpulanmedan had the in-degree follower value of $<100$. This is evidenced in Figure 5 above, where Karo_News and Kumpulanmedan were showed with $<100$ communication links to other nodes. Of the top 15 active \#sinabung users, the average of in-degree follower values is 34.5. The average ratio between the number of followers and its in-degree follower is 2.5\%. @kumpulanmedan and @medanupdate are two Twitter users with the lowest follower:in-degree ratio $(0.3 \%$ and $0.4 \%$ respectively).

An analysis found that the 2745 Indonesian \#sinabung users were geographically distributed widely. Importantly, 532 \#sinabung users are found in North Sumatra province where Mt. Sinabung is located (see Figure 2). Another 58 \#sinabung users (38 and 20, respectively) come from the two nearest cities: Kabanjahe and Berastagi.

The neighboring provinces, such as Aceh (Banda Aceh), Riau (Pekanbaru), West Sumatra (Padang), Jambi, Bengkulu, South Sumatra (Palembang) and Lampung, also had \#sinabung users (31, 33, 25, 8, 3, 21 and 12, respectively). The combined total number of the \#sinabung users, from the affected area and from its surrounding areas, is 665. This number exceeds 588 users from Jakarta, which is clear evidence that the public who live in and near the affected area show active concerns for or interests in the eruption and its impacts as those who live

Table 5: Top 10 Big Nodes: \#sinabung Users.

\begin{tabular}{lrl}
\hline \#sinabung User & Number of Followers & User Characteristic \\
\hline BBCBreaking & $8,694,470$ & International media \\
Detikcom & $6,712,892$ & Indonesian media \\
BBCWorld & $5,540,423$ & International media \\
Metro_TV & $4,982,616$ & Indonesian media \\
GlennFredly & $1,712,537$ & Artist \\
Tifsembiring & 711,490 & Minister of ICT \\
Pak_JK & 698,539 & Head of Red Cross Indonesia, Former Vice President \\
Sudjiwotedjo & 593,734 & Artist \\
anjiii_ & 583,354 & Artist \\
Detikhot & 575,787 & Indonesian media \\
\hline
\end{tabular}


in Jakarta. Jakarta has been ranked as the world's top city in terms of the number of tweets posted (Chatfield and Brajawidagda 2012). Against this, the previous studies on the government disaster agency use of Twitter for tsunami warnings found that the government agency's Twitter followers were located dominantly in Jakarta and Bandung (Chatfield and Brajawidagda 2012; Chatfield et al. 2013).

\subsubsection{The Indonesian Public's Risk Perception Communications via Twitter}

In order to further answer the second question we widened our analysis to include the 2745 Indonesian public, including the 532 living at the edge of Mt. Sinabung discussed above. We then performed another social network analysis on the 2745 unique Indonesian Twitter \#sinabung users to uncover influencers that responded to their risk perceptions, their perceived risks and their perceived fairness of government mass evacuation policies, and their perceptions of government responsiveness to the unfolding disaster.

Table 5 below shows the top 10 big nodes which were determined by \#sinabung users with the greater number of their tweet followers. A specific online social network triggered and formed by the use of the specific hashtag such as \#sinabung can be seen with users sharing their risk perceptions, social concerns and perceived socio-economic impact risks directly related to the current affair of Mt. Sinabung volcanic eruptions. Within this, the ten biggest nodes in this larger online social network tend to represent active \#sinabung users who have built and/or sustained the greater number of followers who follow their tweets during the 1 month from January 4 to February 4 2014, including the February 1 Mt. Sinabung volcanic eruption. Because of the greater number of followers, these big nodes are considered as socially or politically influential in having the latent power to influence their followers on a given topic or issue (Chatfield et al. 2013).

Importantly, as Table 5 below shows, some of them are well known "household names." It appears that the Indonesian public tend to trust and follow their \#sinabung tweets, but not the relatively unknown organizations which may post the greater number of \#sinabung tweets. For example, on the one hand, Karo_News, a local mass media in Karo regency in which Mt. Sinabung is located, showed the greatest in-degree centrality, indicating the greatest connectivity or connection to other \#sinabung users (or other nodes). On the other hand, the locally based Karo_News did not build or sustain the greatest number of followers, and hence it was not one of the 10 big nodes within the 2745 \#sinabung users' online social network during the unfolding disaster period observed and analyzed. Karo_News' hazards and disaster risk tweets posted on the ground nearest the volcano mountain did not generate a greater number of followers vis-à-vis 
that of BBCBreaking (an international media) or that of Metro_TV (a well-known Indonesian media), and hence not being listed in the Table 5 below. Therefore, the public's pre-existing familiarity with and trust in the well-known household names as their preferred disaster risk communicators seems to be an important factor for further discourse. This insight is consistent with empirical evidence found by Parent et al. (2005).

In summary, our research has generated the social network analysis findings on the structure and connectivity of this ad hoc online social network of the 5145 users of the specific hashtag \#sinabung. These users consist of not only local citizens and organizations highly connected to the three Indonesian organizations, such as Karo_News located in Karo Regency near the hazardous volcanic mountain villages, but also the ten big nodes, including major international media (BBCBreaking, BBCWorld), Indonesian media (Detikcom, Metro_TV, Detikhot), politicians (tifsembiring, Pak_JK), artists (sudjiwotedjo and anjii) and a buzzer (Kumpulan Medan).

\subsubsection{The Indonesian Public's Concerns Assessment through Trending Topics Related to the Disaster Risk}

In order to better understand citizens' concerns, we investigated other hashtags the Twitter account holders used concurrently with \#sinabung in a given tweet so as to identify other related issues of citizens' concerns or of further interests. We identified the top 20 issues associated with \#sinabung and we classified these into four types:

- post-disaster sites or ongoing disaster risk locations (\#Manado, \#Indonesia, \#Jakarta, \#medan, \#sumatra, \#banjirJKT, \#marapi and \#raung)

- disaster terms (\#volcano, \#eruption)

- condolences and concerns for the affected (\#prayforsinabung, \#prayforkaro, \#supportforsinabung, \#event, \#jogja and \#pray)

- citizens’ negative sentiments against Indonesia President Dr. Susilo Bambang Yudhoyono (known as “SBY”) (\#unfollowSBY).

When Mt. Sinabung was erupting, Indonesia was struck by other natural disasters such as the floods in Manado and Jakarta. It also faced the increasing hazards and risk from Mt. Marapi (see Table 1) and Mt. Raung. In consequence, the use of the hashtags, such as \#Manado, \#Indonesia, \#Jakarta, \#medan, \#sumatra, \#banjirJKT, \#marapi and \#raung, represents the key trending topics of importance or of social concern in the minds of the hashtag \#sinabung users. Other disaster hashtags, such as \#volcano and \#eruption, seem to highlight the public's risk 
perceptions from the volcanic eruptions. The public also expressed their condolences and concerns for the affected through the hashtag \#prayforsinabung, \#supportforsinabung, \#pray and \#prayforkaro. In the last hashtag, Karo is the name of the local Regency where Mt. Sinabung is located.

Meanwhile the \#event and \#jogja referred to the special event held by people in Jogja, where a concert was held to support the local residents affected by the Mt. Sinabung eruption. Jogja also faced the volcanic hazards and risk from the eruption of Mt. Merapi.

Finally, an interesting hashtag \#unfollowSBY communicates the public anger or outcry against SBY, Indonesia President, who has repeatedly refused to declare a national disaster, maintaining his position that the Mt. Sinabung eruption was a local disaster which did not warrant the aid of the central government for the affected villagers. The \#unfollowSBY users engaged in political campaigns to persuade the followers of SBY to stop following SBY tweets. This hashtag is a useful indicator of the declining external political efficacy defined as perceived government responsiveness (Parent et al. 2005) or as perceived fairness of government procedures and outcomes (Craig et al. 1990).

\section{Discussion and Conclusion}

In this article we have examined three inter-related research questions: (1) How does government use e-government websites and Twitter to communicate their risk perceptions as the disaster dynamically unfolds? (2) How do citizens living near the edge of disaster and the public at safe distances use Twitter hastags to communicate their risk perceptions and concerns? And (3) How does (or can) the effective use of Twitter hashtags influence citizen-centric e-governance in risk communication and external political efficacy (or perceived government responsiveness and perceived fairness of government procedures and outcomes), especially under the uncertain and dynamically changing disaster conditions?

Furthermore, our Twitter analyses found evidence for the absence of government leadership in engaging and shaping the risk communications.

In contrast to the underwhelming use of Twitter by the governments, the Indonesian citizens used Twitter hashtag \#sinabung more proactively and more innovatively in response to the evolving volcano eruptions. Here too, our social network analyses also found evidence for the absence of government engagement in risk perceptions communications and leadership in responding to the Indonesian public's expressed concerns about the affected villages of Mt. Sinabung as a national-level disaster, hence requiring national disaster 
declaration, which would mobilize disaster funds and resources to mount better disaster responses. One would have expected a more proactive and effective use of Twitter \#sinabung by Indonesian governments at all levels in a nation where citizens have embraced the use of Twitter ahead of many other nations in the world.

In the remainder of this section we examine the third question raised in this article: How does (or can) the effective use of social media influence citizencentric e-governance in risk communication and external political efficacy (or perceived government responsiveness and perceived fairness of government policies and procedures), especially under the uncertain and dynamically changing disaster conditions?

\subsection{Citizen-Centric E-Governance}

This paper presented a case study of Indonesian's Mt. Sinabung eruption, which showed evidence for the lack of citizen-centric disaster risk communications on the part of the government. This finding is consistent with the dominant research approaches found in the volcanic hazards and risk literature, which are centrally concerned with the detection and the prediction of diverse types of volcanic hazards and risk.

The analysis of the government websites and Twitter hashtag indicated that the Indonesian government was using e-government as a one-directional risk communication tool to merely inform the public about a disaster situation. The literature on effective emergency management communication indicates that during the enfolding disaster, social media can be more effectively used when there is an increase in citizens' interactions with government since the disaster situations most often dynamically and unpredictably change (Chatfield et al. 2014). As discussed in our Theoretical Foundations section, citizen-centric e-governance enables more involvement and engagement from citizens through digital means. Hence citizen-centric e-governance implemented by government would allow both the government and citizens to be better prepared and more adaptive to the rapid rate of changes in disaster situations. For governments that would implement citizen-centric e-governance, social media can be used effectively as a multi-directional risk communication tool to quickly and effectively share risk perceptions and disaster information with the public through online social networks. This has been witnessed recently with the use of social media to share information and dialogue during the recent natural disasters, including the 2012 Hurricane Sandy (Chatfield et al. 2014) and the 2013 Oklahoma tornado (Chatfield and Brajawidagda 2014). While we still need further social network 
analysis on the tweet data we have collected during the data collection period, the critical examination of social media use by the affected local residents and the public in general seem to be useful towards the design of citizen-centric disaster risk communication vis-à-vis the current government-centric risk communication practice.

\subsection{External Political Efficacy}

External political efficacy, here defined as citizens' perceived government responsiveness to their risk perceptions related timely information in the context of Indonesia's Mt. Sinabung Eruption. For governments there is a need to closely examine and overcome the complex challenges in inter-agency coordination and clear cross-jurisdictional risk communications. In order to improve the current communication of the volcanic hazards and risks, social media and can be part of the solution.

In their study on a simulated evacuation exercise in the context of the potential hazards and risk from the Mt. Katla volcano eruption Bird et al. (2009: p. 263) concluded: "A positive public response during a volcanic crisis not only depends upon the public's knowledge of the evacuation plan but also their knowledge and perception of the possible hazards. To improve the effectiveness of residents' compliance with warning and evacuation messages it is important that emergency management officials understand how the public interpret their situation in relation to volcanic hazards and their potential response during a crisis and apply this information to the ongoing development of risk mitigation strategies." In light of this conclusion and similar conclusions in the literature on volcanic hazards and risk, the alerts and warnings currently in use by the PVMBG needs to be examined for clearer risk communications to those who visit its website. After the 2005-2006 eruption of Augustine volcano in Alaska, the Alaska Volcano Observatory (AVO) improved its ongoing volcano hazards and risk communications to the public, the media, and the aviation community by updating its website information quality and near-real-time data, with more than 45 million web pages and approximately 5.5 terabytes of data (Adleman et al. 2010). Furthermore, the AVO developed and implemented a simple, colorcoded risk assessment and risk communication on volcanic ash emissions: Green (normal); Yellow (signs of unrest); Orange (precursory unrest or minor ash eruption); and Red (major ash eruption imminent or underway). The efficacy of this color code system is evident since it is integrated into procedures of government agencies responsible for air-traffic management and aviation meteorology in Alaska (Guffanti and Miller 2013). 
Historically external political inefficacy of political leaders in response to the rapidly unfolding natural or man-made disasters has proven detrimental to their political capital and political tenure. For example, the George W. Bush administration suffered from the criticism of the government responsiveness to disaster and leadership failures in government mandated mass evacuations in the aftermath of Hurricane Katrina (US House of Representatives 2006). Similarly, Prime Minister Naota Kan in the aftermath of the 2011 Great East Japan Catastrophe resigned under the pressures due to his perceived failure to lead government responses to the enfolding nuclear power plant accidents (The Asahi Shimbun 2011). More recently, South Korean prime minister resigned over his government responsiveness to the ferry boat tragedy that killed many school children (The Sydney Morning Herald 2014). Significantly, Karo Regent Kena Ukur Karo Jambi Surbakti was dismissed by the Karo regency council due to his failure to lead the regency and the perceived poor government responsiveness to the unfolding disaster at Mt. Sinabung (Gunawan 2014). On the other hand, Campbell Newman, then Lord Mayor of Brisbane during the 2011 Queensland floods, decisively responded to the massive floods - despite the government-owned company mismanaged the release of the Wivenhoe dam water which contributed to the floods (ABC 2012), and built a high profile through his charismatic leadership. In March 2012 he won the state election as the 38th Premier of Queensland (Queensland Government 2012).

There are some limitations of this study that should be noted. This paper is limited in that the authors performed a social network analysis of the hashtag \#sinabung. While we have captured 19,394 (or 24\%) tweets out of the total 79,000 tweets posted using \#sinabung during our data collection period of January 4 to February 4, 2014, the Twitter.com data policy and the use of Topsy.com preclude us from adopting a random sampling method. This research is limited in that we did not explore other communication flows besides Twitter and government websites to determine what role that social media had relative to local radio and/ or television. In addition, in Indonesia a limited number of the population in the rural and farming communities as in the Mt. Sinabung area studied in this paper have access to the Internet and Twitter. Finally, we have not discussed in this paper the nature of the emergency, in which other non-digital means are also used to broadcast the emergency.

In terms of future research, perhaps trying to identify false or exaggerated tweets from citizens, their affect on citizens' reaction, and examining ways to reduce or eliminate that potential conflict with official government notifications. Twitter can provide many benefits to citizens during disasters, but there can be issues with misinformation that could more fully be explored in future research. In addition, a qualitative study of perceptions and experiences of 
citizens with respect to governmental communication would also be of value for future research. This research might involve focus groups or interviews with those most impacted by the disaster and their experiences could be carefully examined.

\section{References}

ABC (2012) Queensland Flood Inquiry Finds Dam Mismanaged. Retrieved March 16, 2012, from http://www.abc.net.au/pm/content/2012/s3455378.htm.

Acar, A. and Y. Muraki (2011) "Twitter for Crisis Communication: Lessons Learned from Japan's Tsunami Disaster," International Journal of Web Based Communities, 7(3):392-402.

Adleman, J. N., C. E. Cameron, S. E. Snedigar, C. A. Neal and K. I. Wallace (2010) "Public Outreach and Communications of the Alaska Volcano Observatory During the 2005-2006 Eruption of Augustine Volcano," US Geological Survey Professional Paper, 1769:631-641.

Anderson, M. R. (2010) “Community Psychology, Political Efficacy, and Trust,” Political Psychology, 31(1):59-84.

Annen, C. and J. J. Wagner (2003) “The Impact of Volcanic Eruptions During the 1990s," Natural Hazards Review, 4:169-175.

Baggio, R. (2008) Network Analysis of a Tourism Destination. A PhD Thesis in the School of Tourism of University of Queensland. Retrieved July 11, 2012, from http://www.iby.it/ turismo/papers/baggio_phd-thesis.pdf.

Bales, M., S. B. Johnson and C. Weng (2008) "Social Network Analysis of Interdisciplinarity in Obesity Research," The AMIA Annual Symposium Proceedings, p. 870. Washington, D.C.

Barclay, J., K. Haynes, T. Mitchell, C. Solana, R. Teeuw, A. Darnell, H. Sian Crosweller, P. Cole, D. Pyle, C. Lowe, C. Fearnley, I. Kelman (2008) “Framing Volcanic Risk Communication Within Disaster Risk Reduction: Finding Ways for the Social and Physical Sciences to Work Together," Communicating Environmental Geoscience, 305:163-177.

Bieringer, P. and P. S. Ray (1996) "A Comparison of Tornado Warning Lead Times with and without NEXRAD Doppler Radar," Weather and Forecasting, 11(1):47-52.

Bird, D. K., G. Gisladottir and D. Dominey-Howes (2009) "Resident Perception of Volcanic Hazards and Evacuation Procedures," Natural Hazards and Earth System Science, 9(1):251-266.

Carlino, S., R. Somma and G. C. Mayberry (2008) "Volcanic Risk Perception of Young People in the Urban Areas of Vesuvious: Comparisions with other Volcanic Areas and Implications for Emergency Management," Journal of Valcanology and Geothermal Research, 172:229-243.

Chatfield, A. T. and U. Brajawidagda (2012) "Twitter Tsunami Early Warning Network: A Social Network Analysis of Twitter Information Flows," ACIS 2012: Location, location, location: Proceedings of the 23rd Australasian Conference on Information Systems 2012. ACIS, pp. 1-10. Melbourne, Australia.

Chatfield, A. T. and U. Brajawidagda (2014) "Crowdsourcing Hazardous Weather Reports from Citizens via Twittersphere under the Short Warning Lead Times of EF5 Intensity," Proceedings of the HICSS-47. Hawaii.

Chatfield, A. T., H. J. Scholl and U. Brajawidagda (2013) “Early Tsunami Warning," Government Information Quarterly. Special Issue on Social Media in Government, 30(4):377-386. 
Chatfield, A. T., H. J. Scholl and U. Brajawidagda (2014) “\#Sandy Tweets: Citizens'

Co-Production of Time-Critical Information During an Unfolding Catastrophe," Proceedings of the HICSS-47. Hawaii.

Cheong, F. and C. Cheong (2011) "Social Media Data Mining: A Social Network Analysis of Tweets During The Australian 2010-2011 Floods," Proceedings of the 15th Pacific Asia Conference on Information Systems (PACIS). Brisbane, Australia.

Chung, K. and A. T. Chatfield (2011) "An Empirical Analysis of Online Social Network Structure to Understand Citizen Engagement in Public Policy and Community Building," International Journal of Electronic Governance, 4(1-2):85-103.

Craig, S. C., R. G. Niemi and G. E. Silver (1990) "Political Efficacy and Trust: A Report on the NES Pilot Study Items," Political Behavior, 12(3):289-314.

Davis, M. S., T. Ricci and L. M. Mitchell (2005) "Perceptions of Risk for Volcanic Hazards at Vesuvio and Etna, Italy," The Australasian Journal of Disaster and Trauma Studies, Retreived from http://trauma.massey.ac.nz/issues/2005-1/davis.htm.

Dominey-Howes, D and D. Minos-Minopoulos (2004) “Perceptions of Hazard and Risk on Santorini," Journal of Volcanology and Geothermal Research, 137(4):285-310.

Doswell, C. A., A. R. Moller and H. E. Brooks (1999) "Storm Spotting and Public Awareness Since the First Tornado Forecasts of 1948," Weather and forecasting, 14(4):544-557.

EM-DAT (2012) Available at: http://www.emdat.be/search-details-disaster-list (verify accessed February 2, 2014).

Fee, D. and R. S. Matoza (2013) “An Overview of Volcano Infrasound: From Hawaiian to Plinian, Local to Global," Journal of Volcanology and Geothermal Research, 249:123-139.

Gaillard, J. (2008) “Alternative Paradigms of Volcanic Risk Perception: The Case of Mt. Pinatubo in the Philippines," Journal of Volcanology and Geothermal Research, 172:315-328.

Gaillard, J. and C. Dibben (2008) “Volcanic Risk Perception and Beyond," Journal of Valcanology and Geothermal Research, 172:163-169.

Gauld, R., S. Goldfinch and S. Horsburgh (2010) "Do they Want it? Do they Use it? The "DemandSide" of E-Government in Australia and New Zealand," Government Information Quarterly, 27(2):177-186.

Government Accountability Office (2006a) “Hurricane Katrina GAO’s Preliminary Observations Regarding Preparedness, Response, and Recovery," Statement of David M. Walker Comptroller General of the United States. March 8, 2006, GAO-06-442T.

Government Accountability Office (2006b) “Catastrophic Disasters Enhanced Leaderships, Capabilities, and Accountability Controls Will Improve the Effectiveness of the Nation's Preparedness, Response and Recovery System," September, 2006, GA0-06-618.

Gregg, C. E., B. F. Houghton, D. M. Johnston, D. Paton and D. A. Swanson (2004) “The Perception of Volcanic Risk in Kona Communities from Mauna Lao to Haulalai Volcanoes, Hawaii," Journal of Valcanology and Geothermal Research, 130:179-196.

Guffanti, M. and T. P. Miller (2013) "A Volcanic Activity Alert-level System for Aviation: Review of its Development and Application in Alaska," Natural Hazards, 69(3):1519-1533.

Gunawan, A. (2014) Karo Regent Rejects his Dismissal, The Jakarta Post, Karo. Retrieved March 15, 2014, from http://www.thejakartapost.com/news/2014/03/15/karo-regentrejects-his-dismissal.html.

Haynes, K., J. Barclay and N. Pidgeon (2008) "The Issue of Trust and Its Influence on Risk Communication During a Volcanic Crisis," Bulletin of Volcanology, 70(5):605-621.

International Risk Governance Council (2005) A white paper on risk governance - towards an integrative approach. Retrieved from http://irgc.org/IMG/pdf/IRGC_WP_No_1_Risk_ Governance_reprinted_version_pdf. 
Jaeger, P. T., B. Shneiderman, K. R. Fleischmann, P. R. Preece, Y. Qu and P. Fei Wu (2007) “Community Response Grids: E-government, Social Networks, and Effective Emergency Management," Telecommunications Policy, 31(10-11):592-604.

Johnston, D. M., M. S. Bebbington, C. D. Lai, B. F. Houghton and D. Paton (1999) "Volcanic Hazard Perceptions: Comparative Shifts in Knowledge and Risk," Disaster Prevention and Management, 8(2):118-126.

Kelman, I. and T. A. Mather (2008) "Living with Valcanoes: The Sustainable Livelihoods Approach for Valcano-related Opportunities," Journal of Volcanology and Geothermal Research, 173:189-198.

Khan, G., Y. Ho, J. Kim and H. Park (2014) "From E-government to Social Government: Twitter Use by Korea's Central Government," Online Information Review, 38(1):95 - 113.

Kueppers, U., B. Scheu, O. Spieler and D. B. Dingwell (2006) "Fragmentation Efficiency of Explosive Volcanic Eruptions: A Study of Experimentally Generated Pyroclasts," Journal of Volcanology and Geothermal Research, 153(1-2): SPEC ISS, 125-135.

Lavigne, F., B. De Coster, N. Juvin, F. Flohic, J. C. Gaillard, P. Texier, J. Morine and J. Sartohadi (2008). “People’s Behaviour in the Face of Volcanic Hazards: Perspectives from Javanese Communities, Indonesia," Journal of Volcanology and Geothermal Research, 172(34):273-287.

Leonard, G. S., D. M. Johnston, D. Paton, A. Christianson, J. Becker and H. Keys (2008) "Developing Effective Warning Systems: Ongoing Research at Ruapehu Volcano, New Zealand," Journal of Volcanology and Geothermal Research, 172(3-4):199-215.

Lindell, M. K., S. Arlikatti and C. S. Prater (2009) "Why People do What they Do to Protect Against Earthquake Risk: Perceptions of Hazard Adjustment Attributes," Risk Analysis, 29(8):1072-1088.

Linders, D. (2012) “From E-government to We-Government: Defining a Typology for Citizen Coproduction in the Age of Social Media," Government Information Quarterly, 29(4): 446-454.

Loyola, D., J. Van Geffen, P. Valks, T. Erbertseder, M. Van Roozendael, W. Thomas, W. Zimmer and K. Wibkirchen (2008) "Satellite-Based Detection of Volcanic Sulphur Dioxide from Recent Eruptions in Central and South America," Advances in Geosciences, 14:35-40.

Marti, J. and A. Felpeto (2010) "Methodology for the Computation of Volcanic Susceptibility. An Example for Mafic and Felsic Eruption on Tenerife (Canary Islands)," Journal of Volcanology and Geothermal Research, 195(1):69-77.

Oh, O., M. Agrawal and H. Rao (2013) "Community Intelligence and Social Media Services: A Rumor Theoretic Analysis of Tweets During Social Crisis," MIS Quarterly, 37(2):407-426.

Palen, L. (2008) “Online Social Media in Crisis Events,” Educause Quarterly, 31(3):76-78.

Parent, M., C. A. Vandebeek and A. C. Gemino (2005) "Building Citizen Trust Through E-government," Government Information Quarterly, 22(4):720-736.

Pathon, A. (2014) "Sumatran Eruption Death Toll Expected to Rise," The Sydney Morning Herald, Jakarta, Indonesia, February 3, 2014, p. 13.

Paton, D. and D. Johnston (2001) "Disasters and Communities: Vulnerability, Resilience, and Preparedness," Disaster Prevention and Management, 12(3):210-216.

Paton, D., L. Smith, M. Daley and D. Johnston (2008) "Risk Perception and Volcanic Hazard Mitigation: Individual and Social Perspectives," Journal of Volcanology and Geothermal Research, 172:179-188.

Perry, R. W. and M. K. Lindell (2008) "Volcanic Risk Perception and Adjustment in a Multi-Hazard Environment," Journal of Valcanology and Geothermal Research, 172: 170-178. 
Queensland Government (2012) Campbell Newman Premier of Queensland. Retrieved from http://www.thepremier.qld.gov.au/.

Rahm, D. and C. G. Reddick (2011) “US City Managers' Perceptions of Disaster Risks: Consequences for Urban Emergency Management," Journal of Contingencies and Crisis Management, 19(3):136-146.

Reddick, C. G. (2004) “A Two-stage Model of E-government Growth: Theories and Empirical Evidence for US Cities," Government Information Quarterly, 21(2):51-64.

Reddick, C. G. (2005) “Citizen Interaction with E-government: From the Streets to Servers?” Government Information Quarterly, 22(1):38-57.

Reddick, C. G. (2009) "Factors that Explain the Perceived Effectiveness of E-government: A Survey of United States City Government Information Technology Directors," International Journal of Electronic Government Research, 5(2):1-15.

Reddick, C. G. (2011a) “Citizen-Centric E-governance and Innovative Developments of Public Services," Innovation and the Public Sector, 15:217-233.

Reddick, C. G. (2011b) "Citizen Interaction and E-government Evidence for the Managerial, Consultative, and participatory Models,' Transforming Government: People, Process, and Policy, 5(2):167-184.

Sadowski, M. (2014) Social Media Statistics for Indonesia. Available at: http://socialmemos. com/social-media-statistics-for-indonesia/ (accessed September 4, 2014).

Semiocast (2012) Geolocation Analysis of Twitter Accounts and Tweets by Semiocast, Available at: http://semiocast.com/en/publications/2012_07_30_Twitter_reaches_ half_a_billion_accounts_140m_in_the_US (accessed January 10, 2013).

Sutton, J., L. Palen and I. Shklovski (2008) "Backchannels on the Front Lines: Emergent Uses of Social Media in the 2007 Southern California Wildfires," Proceedings of the 5th International ISCRAM Conference. Washington, D.C.

Sysomos (2010) Exploring the Use of Twitter Around the World, Available at: http://blog. sysomos.com/2010/01/14/exploring-the-use-of-twitter-around-the-world/ (accessed January 10, 2013).

Terpstra, T., M. K. Lindell and J. M. Gutteling (2009) "Does Communicating (Flood) Risk Affect (Flood) Risk Perceptions? Results of a Quasi-Experimental Study," Risk Analysis, 29(8):1141-1155.

The Asahi Shimbun (2011) Row Escalates Over Timing of Kan's Resignation. Retrieved June 3, 2011, from http://ajw.asahi.com/article/0311disaster/fukushima/AJ201106030378.

The Sydney Morning Herald (2014) South Korean PM Resigns Over Government Response to Ferry Disaster. Retrieved April 27, 2014, from http://www.smh.com.au/world/ south-korean-pm-resigns-over-government-response-to-ferry-disaster-20140427-zr09t. html.

Thomas, H. E. and I. M. Watson (2010) "Observations of Volcanic Emissions from Space: Current and Future Perspectives," Natural Hazards, 54(2):323-354.

Tobin, G. A. and L. M. Whiteford (2002) "Community Resilience and Volcano Hazard: The Eruptions of Tungurahua and Evacuation of the Faldas in Ecuador," Disasters, 26(1): 28-48.

Tseng S. F., W. C. Chen and C. L. Chi (2011) "Online Social Media in a Disaster Event: Network and Public Participation,” DICTAP 2011, 167:256-264.

Twitter (2014) Twitter Usages, Available at: https://about.twitter.com/company (accessed September 4, 2014). 
US House of Representatives (2006) A Failure of Initiative. Final Report of the Select Bipartisan Committee to Investigate the Preparation for and Response to Hurricane Katrina. Retrieved February 15, 2006, from http://www.gpoaccess.gov/congress/index.html.

Victorian Bushfires Royal Commission (2010) “Final Report Summary,” Volumes 1-IV. Available at: http://www.royalcommission.vic.gov.au/.

Wachinger, G., O. Renn, C. Begg and C. Kuhlicke (2013) "The Risk Perception ParadoxImplications for Governance and Communication of Natural Hazards," Risk Analysis, 33(6):1049-1065.

Yin, J., A. Lampert, M. Cameron, B. Robinson and R. Power (2012) “Using Social Media to Enhance Emergency Situational Awareness," IEEE Intelligent Systems, 27(6):52-59.

Ying, T. (2010). "Social Networks in the Tourism Industry, an Investigation of Charleston, South Carolina.” In: Clemson University. South Carolina, USA: Clemson University. 
Copyright of Journal of Homeland Security \& Emergency Management is the property of De Gruyter and its content may not be copied or emailed to multiple sites or posted to a listserv without the copyright holder's express written permission. However, users may print, download, or email articles for individual use. 